\title{
Corn Yield Response to Weed and fall ARmyworm Controls ${ }^{1}$
}

\author{
Rendimento do Milho em Resposta ao Controle de Plantas Daninhas e da Lagarta-do-Cartucho
}

\author{
LIMA, M.S. ${ }^{2}$, SILVA, P.S.L. ${ }^{3}$, OLIVEIRA, O.F. ${ }^{4}$, SILVA, K.M.B. ${ }^{5}$ and FREITAS, F.C.L. ${ }^{6}$
}

\begin{abstract}
The interference imposed the by weeds on corn decreases practically all vegetative characteristics. As consequence, the green ear and grain yield are also reduced. Losses due to the fall armyworm (Spodoptera frugiperda) attack can reduce corn grain yield up to $34 \%$. In general, weed and insect control issues are addressed separately in research papers. Nevertheless, interaction between weeds and insects may exist. This study aimed to evaluate green ear and corn grain yield response to weed and fall armyworm control. A completely randomized block design with split-plots and five replicates was adopted. Corn cultivar AG 1051 was grown under weedy conditions or with control by hand hoeings performed at 20 and 40 days after planting. Fall armyworm control (applied to subplots) was performed with sprays of water (control), deltamethrin ( $5 \mathrm{~g}$ active ingredient ha $\left.\mathrm{a}^{-1}\right)$; neem oil, at $0.5 \%$ (diluted in water), and neem leaf extract at $5 \%$. Each product was sprayed three times, at seven-day intervals, starting at the $7^{\text {th }}$ day after planting, using $150 \mathrm{~L} \mathrm{ha}^{-1}$ of the tank solution. Dry mass of the above-ground part, internode diameter, leaf length, leaf width, leaf area, green ear yield and grain yield of corn were reduced due to the lack of weed control. Fall armyworm control in the weeded plots did not influence green ear yield and grain yield, except green mass of marketable, husked ears, which was reduced when the caterpillar was not controlled. Without weed control, neem extracts and deltamethrin sprays provided highest yields of number and total weight of green ears with husks, number and weight of marketable ears with husks and number of marketable ears without husks. The best results for husked ear mass and for grain yield were obtained with neem extract and deltamethrin, respectively.
\end{abstract}

Keywords: Zea mays, Spodoptera frugiperda, Azadirachta indica, weed-pest interaction.

\begin{abstract}
RESUMO - A interferência imposta pelas plantas daninhas ao milho reduz praticamente todas as caracteristicas vegetativas. Em conseqüência, os rendimentos de espigas verdes e degrãos são reduzidos. Perdas devidas ao ataque da lagarta-do-cartucho (Spodoptera frugiperda) podem reduzir o rendimento de grãos em até 34\%. Em geral, os efeitos dos controles das plantas daninhas e das pragas são estudados separadamente. Apesar disso a interação entre interferência de plantas daninhas e ataque de pragas pode existir. O objetivo deste trabalho foi avaliar os rendimentos de espigas verdes e de grãos de milho em resposta ao controle das plantas daninhas e da lagarta-docartucho. Utilizou-se o delineamento de blocos completos casualizados com parcelas subdivididas e cinco repetições. O milho cultivar AG 1051 foi cultivado no mato ou com controle de plantas daninhas por capinas manuais aplicadas aos 20 e 40 dias após a semeadura. Para avaliaro controle do inseto (aplicado às subparcelas) foram feitas pulverizações com: água (testemunha); deltamethrin (5 g do ingrediente ativo ha $\mathrm{h}^{-1}$ ); óleo de nim, obtido comercialmente, à base de 0,5\% (com diluição em água); e extrato foliar de nim, a 5\%. A presença das plantas daninhas reduziu os rendimentos de espigas verdes e de grãos de milho. Nas parcelas capinadas, o controle do inseto não influenciou os rendimentos de espigas verdes e de grãos, exceto a massa de espigas verdes despalhadas comercializáveis, a qual foi reduzida quando não ocorreu o controle da lagarta. Na ausência de capinas, as pulverizações com extrato de nim e com deltamethrin propiciaram os maiores rendimentos
\end{abstract}

1 Recebido para publicação em 20.5.2009 e na forma revisada em 12.3.2010.

2 M.Sc. Student of the Graduate Program in Agronomy, Plant Science, Universidade Federal Rural do Semi-Árido - UFERSA, 59625-900 Mossoró-RN, Brazil, <marilenelima@yahoo.com.br>; ${ }^{3}$ Professor, Plant Science Department, UFERSA, <paulosergio@ufersa.edu.br>; ${ }^{4}$ Professor, Plant Science Department., UFERSA, <odaci@uol.com.br>; ${ }^{5}$ Professor, Biological Sciences Department., Universidade do Estado do Rio Grande do Norte - UERN, 59610-090<kmbsbarbosa@yahoo.com.br>; ${ }^{6}$ Professor, Plant Science Department., UFERSA, <franciscoclaudio@ufersa.edu.br>. 
de número e massa de totais de espigas empalhadas, número e massa de espigas empalhadas comercializáveis e número de espigas despalhadas comercializáveis. Na massa de espigas despalhadas comercializáveis e no rendimento de grãos, os melhores resultados ocorreram com o extrato da nim e com o deltamethrin, respectivamente.

Palavras-chave: Zea mays, Spodoptera frugiperda, Azadirachta indica, interação planta daninha-praga.

\section{INTRODUCTION}

In the State of Rio Grande do Norte, Brazil, corn is grown in the majority of municipalities mostly for green ears, dry grain, and forage. Corn yields are still low due to several constrains, including inadequate control of weeds and pests.

The interference imposed the by weeds on corn decreases practically all vegetative characteristics of the plant (Thomas \& Alisson, 1975; Gomes et al., 2007). As consequence, the green ear and grain yield are also reduced (Silva et al., 2004; Gomes et al., 2007). Weed control in corn is performed by manual, mechanical, and predominantly chemical methods, represented by herbicide spraying. In the Northeastern region of Brazil weed control rarely is done with herbicides- In general, hand hoeing is the major method for weed control.

Spodoptera frugiperda is considered the major insect for the corn crop in Brazil. Corn plants are susceptible to this insect attack during practically all stages of its development cycle, and severe losses occurs when the whorl is destroyed, reducing photosynthetic area and compromising the grain yield. This insect may also attack the basal portion of the ear, destroying the grain or favoring infection by microorganisms (Cruz et al., 1999). The insect attack occurs from plant emergence to tasseling and silking. Losses due to the fall armyworm attack can reduce corn grain yield up to $34 \%$. Losses in Brazil due to attack of this insect are estimated at U\$400 million annually (Figueiredo et al., 2005). Chemical treatment has been the most frequently used control method against $S$. frugiperda. Twenty-nine active ingredients have been recommended for $S$. frugiperda chemical control (Gallo et al., 2002). The pyrethroid deltamethrin was often used in the past and remains as one of the most important available insecticides for insect pests control of corn crops (Badji et al., 2004). In addition, there have been reported cases of $S$. frugiperda resistance evolution in this insect to this group of insecticides used (Figueiredo et al., 2005).

The use of plants that possess insecticidal activity is not a recent technique in insect control, as these plants were commonly used before the advent of synthetic insecticides. In the past decades, as problems of organic synthetic insecticides on insect resistance, effects on natural enemies, environments, and humans increased (Moreira et al., 2006), interest in natural insecticides expanded worldwide. Plants of the Meliaceae family, especially neem, Azadirachta indica, whose insect control has been demonstrated on over 400 species. This plant has repellent, antifeeding, growth-regulating, and insecticidal action, as well as miticidal, fungicidal, and nematicidal activity (Moreira et al., 2006).

Neem oil controls insects due to a number of components with pesticide characteristics. Its main components belong to a class of products known as triterpenes, including azadirachtin, salanin, meliantriol, and nimbin. About $90 \%$ of the effects observed in insects are attributed to azadirachtin. The effects of neem on fall armyworm have been demonstrated mainly under laboratory conditions. The addition of azadirachtin to fall armyworm artificial diet caused reductions in feeding, larval and pupal mortality, as well as anomalies in emerged adults (Martinez \& van Emden, 2001). Both neem seed dust and oil have reduced the survival and development of Helicoverpa zea, S. frugiperda, Diatraea saccharalis, and Diatrea grandiosella (Maredia et al., 1992).

In general, weed and insect control issues are addressed separately in research papers. Nevertheless, interaction between weeds and insects may exist due to several factors 
(Tindall et al., 2005). Weeds compete with corn for water, light, and nutrients, and the severity of the attack of the fall armyworm and other corn insects depends on the crop's nutritional status (Rossi et al., 1987). Some weed species may function as hosts for insect pests and disease-causing agents (Fancelli \& DouradoNeto, 2000). On the other hand, weeds provide food for natural enemies, which are capable of intervening in the attack of corn insects and pathogens.

This study aimed to evaluate green ear and corn grain yield response to weed and fall armyworm control.

\section{MATERIAL AND METHODS}

The experiment was carried out at the "Rafael Fernandes" Experimental Farm at the "Universidade Federal Rural do Semi-Árido" (UFERSA), Mossoró-RN, Brazil (5' ${ }^{\circ}$ latitude, $37^{\circ}$ 20' WGr longitude and an altitude of $18 \mathrm{~m}$ ), with sprinkler irrigation. According to Köppen, the region's bioclimate is classified as BSwh. The soil in the experimental site was a Argissolo Vermelho-Amarelo Eutrófico (Embrapa, 1999), also classified Ferric Lixisol (Fao, 1988), was prepared with two plowings and fertilized with $30 \mathrm{~kg} \mathrm{ha}^{-1} \mathrm{~N}$ (urea), $60 \mathrm{~kg} \mathrm{ha}^{-1}$ of $\mathrm{P}_{2} \mathrm{O}_{5}$ (simple superphosphate) and $30 \mathrm{~kg} \mathrm{ha}^{-1}$ of $\mathrm{K}_{2} \mathrm{O}$ (potassium chloride). The fertilizers were placed in furrows located alongside and below the sowing furrows. The analysis of a sample of the experimental soil indicated: $\mathrm{pH}=6.8 ; \mathrm{Ca}$ $=1.80 \mathrm{cmol}_{\mathrm{c}}^{-1} \mathrm{dm}^{-3} ; \mathrm{Mg}=0.40 \mathrm{cmol}_{\mathrm{c}} \mathrm{dm}^{-3} ; \mathrm{K}=$ $0.10 \mathrm{cmol}_{\mathrm{c}} \mathrm{dm}^{-3} ; \mathrm{Na}=0.01 \mathrm{cmol}_{\mathrm{c}} \mathrm{dm}^{-3} ; \mathrm{Al}=$ $0.00 \mathrm{cmol}_{\mathrm{c}} \mathrm{dm}^{-3} ; \mathrm{P}=25 \mathrm{mg} \mathrm{dm}{ }^{-3}$; Org. Mat. $=$ $19.0 \mathrm{~g} \mathrm{~kg}^{-1}$.

Maize seeds were sowed on $8 / 19 / 2004$, using four seeds per hole. Spacing of $1.0 \mathrm{~m}$ was used between rows and the holes in the same row were spaced by $0.4 \mathrm{~m}$. The thinning was carried out on the 17th day, maintaining the two strongest plants in each hole. Therefore, after thinning, the maize had a populational density of 50 thousand plants ha ${ }^{-1}$. Among the eliminated plants during thinning, 10 were evaluated by: leaf area determination, in order to estimate losses caused by the fall armyworm; quantification of plant damage caused by the insect; and determination of the percentage of plants attacked by the fall armyworm. Damages were quantified using the following rating scale, based on visual observations (in the whole plant) (Lara, 1984): $0=$ no damage; 1 = "scraped" leaves; $2=$ leaves with holes; 3 = leaves with lesions; 4 = "whorl" lesions; and 5 = destroyed "whorl".

A completely randomized block design with split-plots and five replicates was adopted. Each subplot consisted of six rows $6.0 \mathrm{~m}$-long. The evaluation were done in the two central rows, eliminating the plants from one pit at each end $(0,4 \mathrm{~m})$. Maize plants cultivar AG 1051 was submitted to the following groups of treatments: a) without weed control or with control by hand hoeing performed at 20 and 40 days after sowing (main plots); b) fall armyworm control (applied to subplots) by spraying with: water (control); deltamethrin $\left(\right.$ Decis $^{\circledR} 25 \mathrm{CE}, 5 \mathrm{~g}$ active ingredient $\mathrm{ha}^{-1}$ ); neem oil at $0.5 \%$ (diluted in water); and neem leaf extract at $5 \%$. The oil was purchased commercially. The leaf extract was obtained from adult leaves harvested from 8-year-old neem plants. The leaves were dried in the open for 10 days, and then ground and placed in distilled water at a 1:10 ratio $(\mathrm{w} / \mathrm{v})$ for 24 hours. The suspension was strained through a fine-mesh cloth to obtain the extract. Each product was sprayed three times, at seven-day intervals, starting at the $7^{\text {th }}$ day after planting, using $150 \mathrm{~L} \mathrm{ha}^{-1}$ of tank solution, with a backpack sprayer.

Weeds were collected in a sample area of $0.50 \times 0.50 \mathrm{~m}$ (between the two corn plant central rows), at the time mature ears were harvested. The weeds collected were identified and evaluated for fresh and dry mass weight per area unit.

One of the two sub-plot central row were used to evaluate green ear yield and the other was used to evaluate grain yield. Other characteristics were evaluated in both rows. Four green corn harvestings were made, in two or three day intervals, beginning at 68 days after planting. The green corn yield was evaluated by the number and total weight of green ears with husks and by the number and weight of marketable ears with and without husks. Marketable ears with husks were considered to be those measuring $22 \mathrm{~cm}$ or more in length, without stains or evident signs 
of attack from disease or pests. Marketable ears without husks were considered to be those measuring $17 \mathrm{~cm}$ or more in length, with grains and health conditions appropriate for commercialization.

After the green corn was harvested, two plants were taken at random and the following evaluations were made: leaf dimensions and area, internode length and diameter, and biomass of the above-ground part and root system. Leaf area was evaluated using a LI 3100 (LI-COP, Inc. Lincoln, Nebraska, USA) automatic leaf area integrator. Leaf length and width and internode length were measured with a ruler. Internode diameter was obtained with a digital caliper rule. The above-ground part and root system were weighed and then ground into forage. The corn root system was removed with a straight shovel. A soil volume of approximately $0.04 \mathrm{~m}^{3}$ was removed together with the roots, that is, the soil surface layer was removed at a height of $0.25 \mathrm{~m}$, in a $0.40 \times 0.40 \mathrm{~m}$ area, established around the two plants of a pit. A sample of approximately $500 \mathrm{~g}$ of these materials was placed in a air circulation oven adjusted to $75^{\circ} \mathrm{C}$, until the plant biomass reached constant weight, in order to estimate their dry mass values.

Harvest of mature ears was done at approximately 97 days after sowing. After harvest, the number of ears/ha (based on ears harvested in evaluation areas), the number of grains/ear (based on 15 ears), the weight of 100 grains (based on five samples of 100 grains) and the grain yield (of useful plants, corrected for $15.5 \%$ moisture content) were evaluated.

Plant height and ear height were measured in 26 plants of the evaluation area of each subplot after the mature corn was harvested. Plant height was measured in only three replicates, due to plant lodging in some subplots of two replicates, caused by Merremia aegyptia. The distance from ground level to the insertion point of the highest leaf blade was measured as plant height. Ear height was considered as the distance from ground level to the base of the highest ear.

The data were submitted to analysis of variance and the means were compared by Tukey test at $5 \%$ probability, using the SISVAR statistical program (Ferreira, 2003). Prior to running the statistical analyses, the rating and count data were transformed to $(\mathrm{x}+0.5)^{1 / 2}$, to fit a normal distribution.

\section{RESULTS AND DISCUSSION}

Twenty-seven weed species were identified in the experiment area (Table 1). Poaceae, Convolvulaceae, and Rubiaceae were the most frequent plant families. This number is higher than those observed by other authors, in similar studies performed in the

Table 1 - Identified weeds species in the experimental area

\begin{tabular}{|c|c|c|c|}
\hline Botanical name & Family & Botanical name & Family \\
\hline Alternanthera tenella Colla & Amaranthaceae & Ipomoea asarifolia (Desr.) Roem. et Schult.) & Convolvulaceae \\
\hline Amaranthus viridis $\mathrm{L}$. & Amaranthaceae & Ipomoea bahiensis Willd. ex Roem.et Shult. & Convolvulaceae \\
\hline Blainvillea latifolia (L. f.) DC. & Compositae & Macroptilum lathyroides (L.) Urban & Legum. Faboideae \\
\hline Boerhavai difusa L. & Nyctaginaceae & Merremia aegyptia (L.) Urban & Convolvulaceae \\
\hline Cenchrus echinatus $\mathrm{L}$. & Gramineae & Panicum maximum Jacq. & Gramineae \\
\hline Commelina benghalensis $\mathrm{L}$. & Commelinaceae & Richardia grandiflora (Cham. et Schlecht.) Steud. & Rubiaceae \\
\hline Crotalaria retusa $\mathrm{L}$. & Legum. Faboideae & Schrankia leptocarpa DC. & Leg. Mimosoideae \\
\hline Croton lobatus L. & Euphorbiaceae & Senna obtusifolia (L.) Irwin et Barneby & Leg. Caesalpinioideae \\
\hline Cucumis anguria $\mathrm{L}$. & Cucurbitaceae & Sida spinosa L. & Malvaceae \\
\hline Cyperus rotundus $\mathrm{L}$. & Cyperaceae & $\begin{array}{l}\text { Spermacoce vertillata L. [=Borreria verticillata } \\
\text { (L.) G. F. W. Meyer }]\end{array}$ & Rubiaceae \\
\hline Dactyloctenium aegyptium (L.) Beauv. & Gramineae & Turnera ulmifolia L. & Turneraceae \\
\hline Digitaria sanguinalis (L.) Scop. & Gramineae & Trianthema portulacastrum L. & Aizoaceae \\
\hline Eragrostis ciliaris (L.) R. Br. & Gramineae & Waltheria indica $\mathrm{L}$. & Sterculiaceae \\
\hline Euphorbia hirta $\mathrm{L}$. & Euphorbiaceae & & \\
\hline
\end{tabular}


same region (Gomes et al., 2007) The smaller number of weed species was attributed by that author to intensive cropping with corn in the area for more than ten years (two crops per year, involving harrowings and fertilizations). The present experiment, the area had been fallowing for at least five years. The composition and density of weed species is quite variable and is closely associated with the area's cropping history. The biomass of the above-ground part of weeds, as well as the density and diversity of these plants are smaller under conventional cultivation, intermediate in reduced tillage systems, and greater in organic systems (Menalled et al., 2001).

There was not observed any effect of the insect control on weed dry biomass. However, weed control was different from the treatment without weed control with regard to weed dry mass (227.6 $\mathrm{g} \mathrm{m}^{-2}$ and $303.6 \mathrm{~g} \mathrm{~m}^{-2}$, respectively). It is important to point out that in plots involving hoeing, the weed biomass was allowed to grow during the period that followed 40 days after sowing, i.e., the weeds in those plots did not coexist along with the crop during the crop's full cycle.

Plots that did not receive insecticides showed the highest proportion of plants attacked by the fall armyworm (Table 2). In addition, such plants suffered the most damage from the attack of that insect (Table 2). The botanical insecticide effects did not differ from the chemical insecticide effect with regard to both characteristics.

Weed control (WC) and insect control (PC) had an effect on dry mass of the above-ground part of corn, mean internode diameter, mean leaf width, and leaf area; however, no effect was observed for WC x PC interaction (Tables 3 and 4). Biomass reduction by insect activity was caused by reductions in leaf, stem, and root growth, as suggested by the reductions in internode diameter, leaf area, and root system (Table 3). Therefore, fall armyworm activity causes, as expected, smaller corn growth. Leaf area reduction was due to leaf width reduction only, since leaf length was not affected by fall armyworm. Corn biomass reduction because of the lack of weed control was due to the same factors, but in this case the leaf area reduction was also caused by a reduction in leaf length (Table 4). Reductions in corn leaf area due to the presence of weeds have also been observed by other authors (Silva et al., 2004; Gomes et al., 2007). The effects of weed control observed in this study for mean leaf length are in agreement with those found by Gomes et al. (2007), but are contrary to results by the same

Table 2 - Percentage of damaged plants and damage ratings per plant caused by fall armyworm attack, in corn plots ${ }^{1 /}$ (Average of \# plots)

\begin{tabular}{|l|c|c|c|}
\hline \multicolumn{1}{|c|}{$\begin{array}{c}\text { Products } \\
\text { applied }\end{array}$} & $\begin{array}{c}\text { Percentage } \\
\text { of damaged } \\
\text { plants }(\%)\end{array}$ & $\begin{array}{c}\text { Damage rating } \\
\text { (no transformation) }\end{array}$ & $\begin{array}{c}\text { Damage rating } \\
\text { (transformed } \\
\text { data) }\end{array}$ \\
\hline Water & $80 \mathrm{~b}$ & $1.8 \mathrm{~b}$ & $1.5 \mathrm{~b}$ \\
\hline Deltamethrin & $51 \mathrm{a}$ & $0.8 \mathrm{a}$ & $1.2 \mathrm{a}$ \\
\hline Neem extract & $56 \mathrm{a}$ & $1.1 \mathrm{a}$ & $1.3 \mathrm{ab}$ \\
\hline Neem oil & $65 \mathrm{ab}$ & $1.2 \mathrm{a}$ & $1.3 \mathrm{ab}$ \\
\hline $\mathrm{CVa}^{2 /}, \%$ & 26.5 & 24.2 & 9.9 \\
\hline $\mathrm{CVb}^{3 /}, \%$ & 24.3 & 35.0 & 13.4 \\
\hline
\end{tabular}

$1 /$ Means followed by the same letter in the column do not differ at $5 \%$ probability, by Tukey test. 2/ Coefficient of variation experimental for plots. ${ }^{3 /}$ Coefficient of variation experimental for subplots. ${ }^{4 /} 0=$ no damage; $1=$ scraped leaves; $2=$ holes in leaves; 3 = leaves with lesions; $4=$ whorl lesions; and $5=$ destroyed whorl (Lara, 1984). ${ }^{5}$ Transformed to $\sqrt{ } \mathrm{x}+0.5$.

Table 3 - Characteristics of the above-ground part of corn plants as a response to fall armyworm control ${ }^{1 /}$

\begin{tabular}{|l|c|c|c|c|}
\hline $\begin{array}{c}\text { Fall armyworm control } \\
\text { (product applied) }\end{array}$ & $\begin{array}{c}\text { Dry mass } \\
\text { (g per plant) }\end{array}$ & $\begin{array}{c}\text { Internode diameter } \\
(\mathrm{mm})\end{array}$ & $\begin{array}{c}\text { Leaf width } \\
(\mathrm{cm})\end{array}$ & $\begin{array}{c}\text { Leaf area } \\
\left(\mathrm{cm}^{2} \text { per plant }\right)\end{array}$ \\
\hline Water & $84.2 \mathrm{a}$ & $13.7 \mathrm{a}$ & $7.7 \mathrm{a}$ & $3728.7 \mathrm{a}$ \\
\hline Deltamethrin & $106.2 \mathrm{~b}$ & $15.3 \mathrm{ab}$ & $8.2 \mathrm{ab}$ & $4439.5 \mathrm{ab}$ \\
\hline Neem extract & $110.1 \mathrm{~b}$ & $14.9 \mathrm{ab}$ & $8.2 \mathrm{ab}$ & $4069.3 \mathrm{ab}$ \\
\hline Neem oil & $107.1 \mathrm{~b}$ & $15.6 \mathrm{~b}$ & $8.5 \mathrm{~b}$ & $4501.8 \mathrm{~b}$ \\
\hline CV, $\%$ & 16.8 & 9.9 & 7.9 & 14.0 \\
\hline
\end{tabular}

$1^{1}$ Means followed by the same letter do not differ at $5 \%$ probability, by Tukey test. 
Table 4 - Characteristics of the above-ground part of corn plants as a response to weed control ${ }^{1 /}$

\begin{tabular}{|l|c|c|c|c|c|}
\hline $\begin{array}{c}\text { Hoeing } \\
\text { at } 20 \text { and 40 days } \\
\text { after planting }\end{array}$ & $\begin{array}{c}\text { Dry mass of the } \\
\text { above-ground part } \\
(\mathrm{g} \text { per plant })\end{array}$ & $\begin{array}{c}\text { Internode diameter } \\
(\mathrm{mm})\end{array}$ & $\begin{array}{c}\text { Leaf length } \\
(\mathrm{cm})\end{array}$ & $\begin{array}{c}\text { Leaf width } \\
(\mathrm{cm})\end{array}$ & $\begin{array}{c}\text { Leaf area } \\
\left(\mathrm{cm}^{2} \text { per plant) }\right.\end{array}$ \\
\hline With & $120.8 \mathrm{~A}$ & $15.8 \mathrm{~A}$ & $81.0 \mathrm{~A}$ & $8.7 \mathrm{~A}$ & $4989.0 \mathrm{~A}$ \\
\hline Without & $83.0 \mathrm{~B}$ & $13.8 \mathrm{~B}$ & $71.9 \mathrm{~B}$ & $7.6 \mathrm{~B}$ & $3380.6 \mathrm{~B}$ \\
\hline $\mathrm{CV}, \%$ & 37.4 & 6.8 & 5.0 & 5.3 & 10.2 \\
\hline
\end{tabular}

${ }^{1 /}$ Means followed by the same letter do not differ at $5 \%$ probability, by Tukey test.

author as to mean leaf width. No studies were found reporting on the influence of fall armyworm control on internode length and diameter.

Mean internode length remained unchanged by two groups of treatments $(14 \mathrm{~cm}$ on average, Coefficient of Variation Experimental for plots $=\mathrm{CVa}=8.4 \%$ and Coefficient of Variation Experimental for subplots $\mathrm{CVb}=9,5 \%$ ); the same was verified for plant height $(178 \mathrm{~cm}$ on average, $\mathrm{CVa}=$ $7.8 \%$ and $\mathrm{CVb}=5.6 \%)$ and ear height $(104 \mathrm{~cm}$ on average, $\mathrm{CVa}=9.9 \%$ and $\mathrm{CVb}=7.4 \%$ ). These results are in agreement with those found by Gomes et al. (2007), but differ from those found by Rossi et al. (1996), who observed a reduction in ear height due to the presence of weeds.

The effects of both treatment groups were similar for all characteristics used to evaluate green ear yield, except for mass of marketable, husked green ears (Table 5). In other words, except for mass of marketable husked ears, there were no differences between caterpillar control treatments when the plots were hoed. There were no differences between fall armyworm control treatments with respect to total number and weight of green ears, number and weight of marketable unhusked ears, and number of marketable husked green ears when the plots were hoed. When the plots were not hoed, corn plants sprayed with water yielded less than plants in plots that received insecticides. As to the mass of marketable husked ears, there were differences between fall armyworm control treatments in hoed and non-hoed plots. In this trait, plant spraying again provided the lowest yield values in hoed plots. However, marketable husked green ear mass values in plots sprayed with water or neem extract were similar in non-hoed plots.
In spite of that, neem oil treatment provided similar results as deltamethrin only when weeds were controlled. In all fall armyworm control treatments, except for total number of ears and number of marketable unhusked ears, neem extract spray in hoed plots determined higher yields than in non-hoed plots. (Table 5). Other authors (Silva et al., 2004; Gomes et al., 2007) also verified a reduction in green corn yield resulting from competition between the corn and the weeds.

There was a weed control effect (WC) on grain yield and its components (number of mature ears ha ${ }^{-1}$, number of grains ear ${ }^{-1}$, and 100-grain weight) and on ear characteristics (number of kernel rows, and ear length and diameter) (Tables 6 and 7). Fall armyworm control effect (PC) was only observed on grain yield and ear length (Table 6) and on number of mature ears ha ${ }^{-1}$ (estimated by the total number of green ears, Table 5). The WC x PC interaction only occurred on these three characteristics. As with most characteristics used to evaluate green corn yield (Table 5), there was a pest control effect on these characteristics in non-hoed plots only (Table 5). Use of deltamethrin provided the highest grain yield. Yield differences between pest control treatments resulted from differences in the number of ears ha ${ }^{-1}$, since the two other yield components were not influenced by the sprays. With regard to weed control, the grain yield reduction occurred because of reductions in the three yield components (number of mature ears ha-1, number of grains ear ${ }^{-1}$, and 100grain weight).

The lack of weed control reduced most characteristics evaluated in this study. Weeds presence reduced maize green ear and grain yields, as well as other maize characteristics, in the non-weeded subplots. Weeds presence 
Table 5 - Green ear yield of corn cultivar AG 1051 as a response to weed and fall armyworm control ${ }^{1 /}$

\begin{tabular}{|c|c|c|c|c|}
\hline \multirow{3}{*}{$\begin{array}{c}\text { Fall armyworm } \\
\text { control } \\
\text { (product applied) }\end{array}$} & \multicolumn{2}{|c|}{$\begin{array}{c}\text { Weed control } \\
\text { (hoeing at } 20 \text { and } 40 \text { days after planting) }\end{array}$} & \multicolumn{2}{|c|}{$\begin{array}{c}\text { Weed control } \\
\text { (hoeing at } 20 \text { and } 40 \text { days after planting) }\end{array}$} \\
\hline & Hoeing & No hoeing & Hoeing & No hoeing \\
\hline & \multicolumn{2}{|c|}{ Total number of green ears ha ${ }^{-1}$} & \multicolumn{2}{|c|}{ Total green ear mass $\left(\mathrm{kg} \mathrm{ha}^{-1}\right)$} \\
\hline Water & $45024 \mathrm{~A} \mathrm{a}$ & $22016 \mathrm{~B} \mathrm{a}$ & $15359 \mathrm{~A} \mathrm{a}$ & $7559 \mathrm{~B} \mathrm{a}$ \\
\hline Deltamethrin & $46898 \mathrm{~A} \mathrm{a}$ & $34779 \mathrm{~B} \mathrm{~b}$ & $17422 \mathrm{~A} \mathrm{a}$ & $11542 \mathrm{~B} \mathrm{~b}$ \\
\hline Neem extract & $46550 \mathrm{~A} \mathrm{a}$ & $39378 \mathrm{~A} \mathrm{~b}$ & $16772 \mathrm{~A} \mathrm{a}$ & $12237 \mathrm{~B} \mathrm{~b}$ \\
\hline Neem oil & $47004 \mathrm{~A} \mathrm{a}$ & $32041 \mathrm{~B} \mathrm{ab}$ & $16311 \mathrm{Aa}$ & $10144 \mathrm{~B} \mathrm{ab}$ \\
\hline $\mathrm{CVa}^{2}, \%$ & \multicolumn{2}{|c|}{10.7} & \multicolumn{2}{|c|}{9.3} \\
\hline $\mathrm{CVb}^{3}, \%$ & \multicolumn{2}{|c|}{14.9} & \multicolumn{2}{|c|}{13.6} \\
\hline Products applied & \multicolumn{2}{|c|}{ Number of marketable unhusked green eas ha ${ }^{-1}$} & \multicolumn{2}{|c|}{ Mass of marketable unhusked green ears $\left(\mathrm{kg} \mathrm{ha}^{-1}\right)$} \\
\hline Water & $45024 \mathrm{~A} \mathrm{a}$ & $22016 \mathrm{~B} \mathrm{a}$ & $14554 \mathrm{~A} \mathrm{a}$ & $5664 \mathrm{~B} \mathrm{a}$ \\
\hline Deltamethrin & $46898 \mathrm{~A} \mathrm{a}$ & $34779 \mathrm{~B} \mathrm{~b}$ & $16954 \mathrm{~A} \mathrm{a}$ & $9778 \mathrm{~B} \mathrm{~b}$ \\
\hline Neem extract & $46550 \mathrm{~A} \mathrm{a}$ & $39378 \mathrm{~A} \mathrm{~b}$ & $16333 \mathrm{~A} \mathrm{a}$ & $11148 \mathrm{~B} \mathrm{~b}$ \\
\hline Neem oil & $47004 \mathrm{~A} \mathrm{a}$ & $32041 \mathrm{~B} \mathrm{ab}$ & $15863 \mathrm{Aa}$ & $7608 \mathrm{~B} \mathrm{ab}$ \\
\hline $\mathrm{CVa}^{2}, \%$ & \multicolumn{2}{|c|}{10.7} & \multicolumn{2}{|c|}{17.5} \\
\hline $\mathrm{CVb}^{3}, \%$ & \multicolumn{2}{|c|}{14.9} & \multicolumn{2}{|c|}{17.6} \\
\hline Products applied & \multicolumn{2}{|c|}{ Number of marketable husked green ears ha ${ }^{-1}$} & \multicolumn{2}{|c|}{ Mass of marketable husked green ears $\left(\mathrm{kg} \mathrm{ha}^{-1}\right)$} \\
\hline Water & $37726 \mathrm{~A} \mathrm{a}$ & $15173 \mathrm{~B} \mathrm{a}$ & $8200 \mathrm{~A} \mathrm{a}$ & $3302 \mathrm{~B} \mathrm{a}$ \\
\hline Deltamethrin & $41021 \mathrm{~A} \mathrm{a}$ & $22610 \mathrm{~B} \mathrm{~b}$ & $9782 \mathrm{~A} \mathrm{~b}$ & $4429 \mathrm{~B} \mathrm{ab}$ \\
\hline Neem extract & $41167 \mathrm{~A} \mathrm{a}$ & $26463 \mathrm{~B} \mathrm{~b}$ & $8998 \mathrm{~A} \mathrm{~b}$ & $5396 \mathrm{~B} \mathrm{~b}$ \\
\hline Neem oil & $41078 \mathrm{~A} \mathrm{a}$ & $20702 \mathrm{~B} \mathrm{ab}$ & $8907 \mathrm{~A} \mathrm{ab}$ & $3398 \mathrm{~B} \mathrm{a}$ \\
\hline $\mathrm{CVa}^{2}, \%$ & \multicolumn{2}{|c|}{13.6} & \multicolumn{2}{|c|}{12.0} \\
\hline $\mathrm{CVb}^{3}, \%$ & \multicolumn{2}{|c|}{13.3} & \multicolumn{2}{|c|}{11.1} \\
\hline
\end{tabular}

1/ Means followed by the same upper case letter in the row, or same lower case letter in the column do not differ at $5 \%$ probability, by Tukey test. ${ }^{2 /}$ Coefficient of variation experimental for plots. ${ }^{3 /}$ Coefficient of variation experimental for subplots.

reduce crop yield by competing with them for water, nutrients and light (Carruthers et al., 1998). Removal of nutrients by weeds from soil solution impacts on nutrient availability for the crop, thus affecting its accumulation of dry matter (Sreenivas \& Satyanarayana, 1996). However, other factors are involved during competition between corn and weeds. Corn root system is under developed with weeds are present (Thomas \& Allison, 1975). Thus, a smaller corn root system due to weed presence would be less efficient in nutrient absorption. An important characteristic of corn is that most of sun light is intercepted by the younger, more efficient leaves above the ear and less than $10 \%$ of the photon flux density (PFD) reaches the leaves below $1 \mathrm{~m}$. On the other hand, most weeds are under $1 \mathrm{~m}$ in height at blooming and after blooming. That means that corn yield loss due to competition with weeds for PFD cannot be explained by the reduced photosynthetic rates of the lower leaves shaded by weeds. Leaf area index (LAI) defines the ability of a plant to intercept PFD and it is an important determining factor for the accumulation of dry matter. A high degree of competition with weeds was seen (Tollenaar et al., 1994) to reduce corn LAI at blooming by $15 \%$. Thus, grain yield loss resulting from competition for light is best explained through LAI reduction than in lower photosynthetic rates of shaded leaves (Rajcan \& Swanton, 2001). In the present experiment a reduction was observed in the corn leaf area (Table 3), which agrees with other authors (Aflakpui et al., 2002), due to competition with weeds. Other authors (Ford \& Pleasant, 1994) also verified a reduction in the number of corn leaves due to weed presence. Reduction in corn leaf area (Table 3) should increase light on weeds making them more aggressive against corn. 
Table 6 - Mean corn grain yield and ear length as a response to weed and fall armyworm control ${ }^{1 /}$

\begin{tabular}{|c|c|c|c|c|}
\hline \multirow{3}{*}{$\begin{array}{l}\text { Fall armyworm control } \\
\text { (product applied) }\end{array}$} & \multicolumn{2}{|c|}{$\begin{array}{c}\text { Weed control } \\
\text { (hoeing at } 20 \text { and } 40 \text { days after planting) }\end{array}$} & \multicolumn{2}{|c|}{$\begin{array}{c}\text { Weed control } \\
\text { (hoeing at } 20 \text { and } 40 \text { days after planting }\end{array}$} \\
\hline & Hoeing & No hoeing & Hoeing & No hoeing \\
\hline & \multicolumn{2}{|c|}{ Grain yield $\left(\mathrm{kg} \mathrm{ha}^{-1}\right)$} & \multicolumn{2}{|c|}{ Ear length $(\mathrm{cm})$} \\
\hline Water & $8702.00 \mathrm{~A} \mathrm{a}$ & $3204.00 \mathrm{~B} \mathrm{a}$ & $15.80 \mathrm{~A} \mathrm{a}$ & $11.20 \mathrm{~B} \mathrm{a}$ \\
\hline Deltamethrin & $8953.80 \mathrm{~A} \mathrm{a}$ & $5540.60 \mathrm{~B} \mathrm{~b}$ & $15.60 \mathrm{~A} \mathrm{a}$ & $14.00 \mathrm{~B} \mathrm{~b}$ \\
\hline Neem extract & $9986.80 \mathrm{~A} \mathrm{a}$ & $3510.40 \mathrm{~B} \mathrm{a}$ & $16.40 \mathrm{~A} \mathrm{a}$ & $12.40 \mathrm{~B} \mathrm{ab}$ \\
\hline Neem oil & $9180.20 \mathrm{~A} \mathrm{a}$ & $4003.60 \mathrm{~B} \mathrm{ab}$ & $16.00 \mathrm{~A} \mathrm{a}$ & $12.00 \mathrm{~B} \mathrm{a}$ \\
\hline $\mathrm{CVa}^{2}, \%$ & \multicolumn{2}{|c|}{15.1} & \multicolumn{2}{|c|}{9.9} \\
\hline $\mathrm{CVb}^{3}, \%$ & \multicolumn{2}{|c|}{13.9} & \multicolumn{2}{|c|}{7.8} \\
\hline
\end{tabular}

${ }_{1 /}^{1 /}$ Means followed by the same upper case letter in the row, or same lower case letter in the column do not differ at 5\% probability, by Tukey test. ${ }^{2 /}$ Coefficient of variation experimental for plots. ${ }^{3 /}$ Coefficient of variation experimental for subplots.

Table 7 - Means for 100-grain weight, number of grain rows in the ear, number of kernels ear ${ }^{-1}$, and corn ear diameter as a response to weed control ${ }^{1 /}$

\begin{tabular}{|c|c|c|c|c|}
\hline $\begin{array}{c}\text { Hoeing at 20 and 40 days } \\
\text { after planting }\end{array}$ & $\begin{array}{c}\text { 100-grain weight } \\
(\mathrm{g})\end{array}$ & $\begin{array}{c}\text { Number of grain rows } \\
\text { in ear }\end{array}$ & Number of grains ear ${ }^{-1}$ & $\begin{array}{c}\text { Ear diameter } \\
(\mathrm{cm})\end{array}$ \\
\hline With & $36.5 \mathrm{a}$ & $15.3 \mathrm{a}$ & $524 \mathrm{a}$ & $51.6 \mathrm{a}$ \\
\hline Without & $23.6 \mathrm{~b}$ & $14.1 \mathrm{~b}$ & $346 \mathrm{~b}$ & $42.3 \mathrm{~b}$ \\
\hline $\mathrm{CVa}^{2}, \%$ & 15.9 & 6.1 & 21.0 & 11.1 \\
\hline $\mathrm{CVb}^{3 /}, \%$ & 11.8 & 5.6 & 16.6 & 6.5 \\
\hline
\end{tabular}

${ }^{1 /}$ Means followed by the same letter do not differ at $5 \%$ probability, by Tukey test. ${ }^{2 /}$ Coefficient of variation experimental for plots. ${ }^{3 /}$ Coefficient of variation experimental for subplots.

In many characteristics, fall armyworm control effect only occurred in non-hoed plots, that is, there was an interaction weed control $x$ insect control. Weeds might provide shelter for insects, especially in non-hoed plots. High weed density results in increased population of the insect and, consequently, greater damages to the crop are caused (Tindall et al., 2005). Insect damage reduces crop vigor, making the crop more susceptible to weed infestation (Norris \& Kogan, 2000). Insects also may have a negative effect on hoed plots, especially under heavy infestations. In the present work, infestation by the insect was not evaluated. The lack of insect control had a detrimental effect on some characteristics, and this may have occurred due to a greater proportion of attacked plants and greater damage to those plants.

Green ear yield, grain yield, and most other characteristics evaluated were reduced due to the lack of weed control. Pest control in the weeded plots did not influence green ear yield and grain yield, with the exception of green mass of marketable, husked ears, which was reduced when the caterpillar was not controlled. Without weed control, neen extracts or deltamethrin sprays provided the best green corn characteristics, except for husked ear mass. The best results for this characteristic and for grain yield were obtained with neem extract and deltamethrin, respectively.

\section{LITERATURE CITED}

AFLAKPUI, G. K. S.; GREGORY, P. J.; FROUDWILLIAMS, R. J. Growth and biomass partitioning of maize during vegetative growth in response to Striga hermonthica infection and nitrogen supply. Exper. Agric., v. 38, n. 1, p. 265-276, 2002.

BADJ, C. A.; GUEDES, R. N. C.; SILVA, A. A. Impact of deltamethrin on arthropods in maize under conventional and no-tillage cultivation. Crop Protec., v. 23, n. 11, p. $1031-1039,2004$ 
CARRUTHERS, K.; FE, Q.; CLOUTIER, D.; SMITH, D. L. Intercropping corn with soybean, lupin and forages: weed control by intercrops combined with interrow cultivation. Europ. J. Agron., v. 8, n. 3, p. 225-238, 1998.

CRUZ, I. et al. Damage of Spodoptera frugiperda (Smith) in different maize genotypes cultivated in soil under three levels of aluminium saturation. Inter. J. Pest Manag., v. 45, n. 4, p. 293-296, 1999.

EMPRESA BRASILEIRA DE PESQUISA AGROPECUÁRIA - EMBRAPA. Centro Nacional de Pesquisa do Solo. Sistema brasileiro de classificação de solos. Brasília: Serviço de Produção de Informação, 1999. $412 \mathrm{p}$.

FAO. Soil map of the world: revised legend. Rome: UNESCO, 1988. 119 p.

FANCELLI, A. L.; DOURADO-NETO, D. Produção de milho. Guaíba: Agropecuária, 2000. 360 p.

FERREIRA, D. F. SISVAR (Sistema para análise de variância): versão 4.3 (Build 46). Lavras: Universidade Federal de Lavras, 2003.

FIGUEIREDO, M. L. C.; PENTEADO-DIAS, A. M.; CRUZ, I. Danos provocados por Spodoptera frugiperda na produção de matéria seca e nos rendimentos de grãos, na cultura do milho. Sete Lagoas: Embrapa/CNPMS, 2005. 6 p (Comunicado Técnico, 130)

FORD, G. T.; PLEASANT, J. Competitive abilities of six corn (Zea mays L.) hybrids with four weed control practices. Weed Technol., v. 8, n. 3, p. 124-128, 1994.

GALLO, D. et al. Entomologia agrícola. Piracicaba: FEALQ, 2002. 920 p.

GOMES, J. K. O. et al. Effects of weed control through cowpea intercropping on mayze morphology and yield. Planta Daninha, v. 25, n. 3, p. 433-441, 2007.

LARA, F. M.; AYALA OSUNA, J.; ABDELNUR JÚNIOR, O. Comportamento de genótipos de milho em relação ao ataque de Spodoptera frugiperda (J.E. Smith, 1977) e Heliothis zea (BOD, 1850). Científica, v. 12, n. 1/2, p. 77-83, 1984.

MAREDIA, K. M.; SEGURA, O. L.; MIHM, J. A. Effects of neem, Azadirachta indica, on six species of maize insect pests. Trop. Pest Manag., v. 38, n. 2, p. 190-195, 1992.
MARTINEZ, S. S.; van EMDEN, H. F. Growth disruption, abnormalities and mortality of Spodoptera littoralis (Boisduval) (Lepidoptera: Noctuidae) caused by Azadirachtin. Neotrop. Entomol., v. 30, n. 1, p. 113-125, 2001.

MENALLED, F. D.; GROSS, K. L.; HAMMOND, M. Weed aboveground and seedbank community responses to agricultural management systems. Ecol. Appl., v. 11, n. 6, p. 1586-1601, 2001.

MORREIRA, M. D. et al. Uso de inseticidas botânicos no controle de pragas. In: VENZON, M.; PULA JUNIOR, T. J.; PALINNI, A. controle alternativo de pragas e doenças. Viçosa, MG: EPAMING/CTZM/UFV, 2006. p. $89-120$

NORRIS, R. E.; KOGAN, M. Interactions between weeds, arthropod pests and their natural enemies in management ecosystems. Weed Sci., v. 48, n. 1, p. 94-158, 2000.

RAJCAN, I.; SWANTON, C. J. Understanding maize-weed competition: resource competition, light quality and the whole plant. Field Crops Res., v. 71, n. 2, p. 139-150, 2001.

ROSSI, I. H. et al. Interferência das plantas daninhas sobre algumas características agronômicas e a produtividade de sete cultivares de milho. Planta Daninha, v. 14, n. 2, p. 134-148, 1996.

ROSSI, C. E. et al. Influência de diferentes adubações em milho sobre Spodoptera frugiperda (J.E. Smith, 1797) (Lepidóptera: Noctuidade). Ecossistema, v. 12, n. 1, p. 88-101, 1987.

SILVA, P. S. L.; SILVA, E. S.; MESQUTTA, S. S. X. Weed control and green ear yield in maize. Planta Daninha, v. 22, n. 1, p. 137-144, 2004.

SREENIVAS, G.; SATYANARAYANA, V. Nutrient removal by weeds and maize. Indian J. Agron., v. 41, n. 1, p. 160-162, 1996.

TINDALL, K. V. et al. Yield components quality of rice in response to graminaceous weed density and rice stink bug populations. Crop Protec., v. 24, n. 11, p. 991-998, 2005.

THOMAS, P. E. L.; ALLISON, J. C. S. Competition between maize and Rottboellia exaltata. J. Agric. Sci., v. 84, n. 1, p. 305-312, 1975.

TOLLENAAR, M. et al. Effect of weed interference and soil nitrogen on four maize hybrids. Agron. J., v. 86, n. 2 , p. 596-601, 1994. 